\title{
Pyroderus scutatus masoni (Shaw, 1792) (Aves, Cotingidae): a subspecies of Red-ruffed Fruitcrow newly confirmed for Ecuador
}

\author{
Leonardo Ordóñez-Delgado, ${ }^{1}$ Santiago Erazo, ${ }^{2}$ Ivonne González, ${ }^{3}$ Diego Armijos-Ojeda, ${ }^{1}$ \\ Daniel Rosado ${ }^{3}$
}

1 Universidad Técnica Particular de Loja, Departamento de Ciencias Biológicas, Laboratorio de Ecología Tropical y Servicios EcosistémicosEcoSs Lab. Calle París S/N, CP: EC11-01-608, Loja, Ecuador. 2 Universidade Federal do Pará/EMBRAPA Amazônia, Laboratório de Ecologia e Zoologia de Vertebrados, Programa de Pós Graduação em Ecologia, Belém, Para, Brazil. 3 Universidad Técnica Particular de Loja, Departamento de Ciencias Biológicas, Calle París S/N, CP: EC11-01-608, Loja, Ecuador.

Corresponding author: Leonardo Ordóñez-Delgado, lyordonez2@utpl.edu.ec

\begin{abstract}
We present the first records of the Red-ruffed Fruitcrow, Pyroderus scutatus (Shaw, 1792), in the Cordillera del Cóndor of Ecuador and the first confirmed records of this species in the east of this country. These new records were made in October 2016 and February and September 2017 in the Blanco river basin in southeastern Ecuador. This place is $200 \mathrm{~km}$ and over $500 \mathrm{~km}$ from the nearest occurrences of this species in Peru and Ecuador, respectively. We can now confirm the presence of the subspecies P. s. masoni (Ridgway, 1886) in Ecuador.
\end{abstract}

Keywords

Distribution; range extension; Cordillera del Cóndor, Zamora Chinchipe.

Academic editor: Johan Ingels | Received 29 September 2017 | Accepted 11 January 2018 | Published 23 February 2018

Citation: Ordóñez-Delgado L, Erazo S, González I, Armijos-Ojeda D, Rosado D (2018) Pyroderus scutatus masoni (Shaw, 1792) (Aves, Cotingidae): a subspecies of Red-ruffed Fruitcrow newly confirmed for Ecuador. Check List 14 (1): 281-284. https://doi.org/10.15560/14.1.281

\section{Introduction}

The Red-ruffed Fruitcrow, Pyroderus scutatus (Shaw, 1792) (Aves, Cotingidae), is a large cotinga (male $413 \mathrm{~g}$, $43 \mathrm{~cm}$; female $419 \mathrm{~g}, 38 \mathrm{~cm}$ ) that occurs locally in Ecuador, Colombia, Venezuela, Peru, Guyana, Brazil, Paraguay, and Argentina (Kirwan et al. 2011, Snow and Bonan 2017) (Fig. 1). It inhabits mainly humid mountain forests and has an omnivorous diet, including various fruits and large insects (Snow and Bonan 2017) and sometimes vertebrates, such as frogs (Intervales 2011). According to the IUCN Red List of Threatened Species, the species is globally of Least Concern (BirdLife International 2016). However, it is an uncommon to rare species with an irregular distribution (Stotz et al. 1996) and populations are decreasing due to the loss of habitat and hunting, as sometimes this species is considered to be a game bird (Snow and Bonan 2017).

\section{Methods}

As part of a biomonitoring carried out on 25 October 2016 in the Blanco river basin, which is located in Paquisha canton, Zamora Chinchipe province in southeastern Ecuador, we documented individuals of $P$. scutatus using photography and sound recording.

The recordings of song were deposited in the XenoCanto database (Ordóñez-Delgado 2017). 

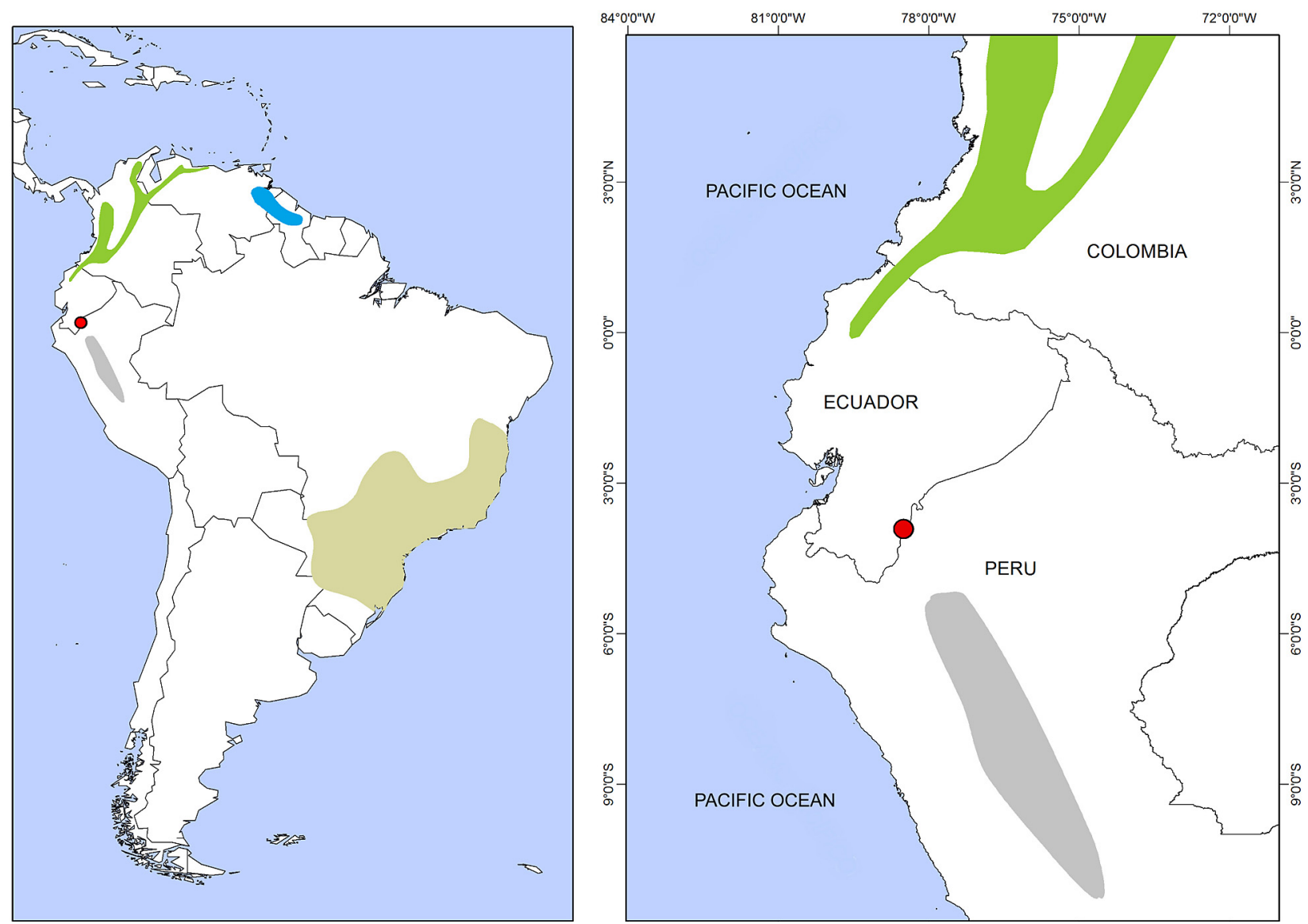

Figure 1. Left: distribution map of the Red-ruffed Fruitcrow Pyroderus scutatus with subspecies P. s. occidentalis and P. s. granadensis (green), P. s. orenocensis (blue), P. s. scutatus (brown), P. s. masoni (gray) based in (Snow and Bonan 2017). Right: details of record of P. s. masoni in the Cordillera del Cóndor region of Ecuador (red dot).

\section{Results}

New records. Ecuador, Zamora Chinchipe, Cordillera del Cóndor ( $03^{\circ} 54.86^{\prime} \mathrm{S}, 078^{\circ} 30.47^{\prime} \mathrm{W}, 1,710 \mathrm{~m}$ elev. $)$, Santiago Erazo, 25 October 2016, photographed, 1 individual. Ecuador, Zamora Chinchipe, Cordillera del Cóndor ( $03^{\circ} 56.04^{\prime} \mathrm{S}, 078^{\circ} 30.00^{\prime} \mathrm{W}, 1,920 \mathrm{~m}$ elev. $)$, Leonardo Ordóñez-Delgado, 14 and 15 February 2017, duet recorded: XC387672, XC387670, 2 individuals. Ecuador, Zamora Chinchipe, Cordillera del Cóndor $\left(03^{\circ} 56.04^{\prime} \mathrm{S}\right.$, $\left.078^{\circ} 30.00^{\prime} \mathrm{W}\right)$, Leonardo Ordóñez-Delgado, 4 September 2017, photographed (Fig. 2) and songs recorded: XC387768, XC387769, XC387770, 1 individual.

The second observation (14 and 15 February 2017) was made approximately $2.4 \mathrm{~km}$ southeast of the first observation site. On this occasion, an adult individual was seen at $08.00 \mathrm{~h}$ in the canopy of a dense mature forest where it was foraging in the crown of a tree, Pourouma Aubl. (Urticaceae). At around $09.00 \mathrm{~h}, 2$ duets could be heard inside the forest. Both birds emitted the characteristic loud and unmistakable uиит, ииит, ииит of this species.

The last observation (4 September 2017) was in the same area as the previous. Photographs (Fig. 2) were taken and recordings made. On this occasion, an adult individual was observed for less than 15 min perching about $8-10 \mathrm{~m}$ above the ground in the crown of a tree (Melastomatacea).
We found it relatively easy to hear this species during mornings from $07.00 \mathrm{~h}$ to $09.00 \mathrm{~h}$ and in afternoons from $16.30 \mathrm{~h}$ onwards.

Identification. The species and subspecies were identified based on characteristics described by Ridgely and Greenfield (2001b), Schulenberg et al. (2010), Kirwan et al. (2011), and the Internet Bird Collection (http://www. hbw.com/ibc). The photographed individual was a large bird with a black upperside and a contrasting orange, nearly crimson, chin and chest. The ventral part was dull, dark brown, with a mottled pattern that disappears progressively to the undertail coverts, where it is negligible. A black necklace divides the chest and belly (Fig. 2). This color pattern differentiates P. s. masoni (Ridgway, 1886) from the other 3 subspecies, including P. s. occidentalis Chapman, 1914, the subspecies recorded so far from Ecuador. The ventral coloration is more intense and uniform in P. s. occidentalis (Brinkhuizen 2014). Thus, we can confirm the presence of P. s. masoni in Ecuador based on our field notes and photographs.

Our new records are from an evergreen montane forest within the Cordillera del Cóndor (Ministerio del Ambiente de Ecuador 2013). In this area, the vegetation is characteristic of the Amazon lowlands and the eastern slope of the Andes, with trees between 5 and $25 \mathrm{~m}$ high (Ordóñez-Delgado et al. 2017). Some of the most 


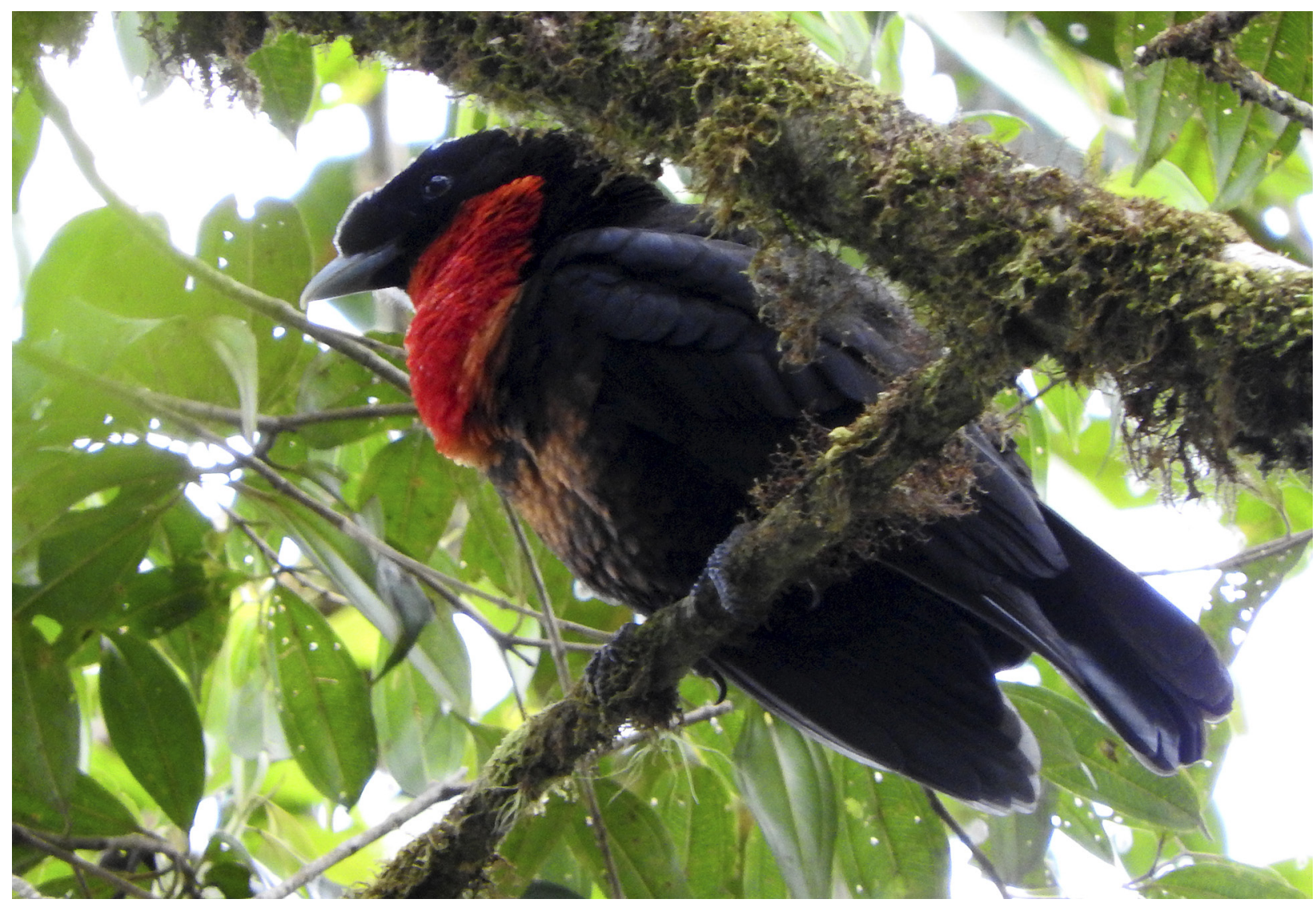

Figure 2. Photograph of Red-ruffed Fruitcrow Pyroderus scutatus masoni taken in the Cordillera del Cóndor region of Ecuador, with details of the head, throat, chest and belly. Photograph by L. Ordóñez-Delgado.

representative botanical species of this area are Clarisia racemosa Ruiz \& Pav., Dacryodes cupularis Cuatrec., Miconia punctata (Desr.) D. Don ex DC., Nectandra cissiflora Nees, Weinmannia elliptica Kunth, and Wettinia maynensis Spruce (Jadán and Aguirre 2011).

\section{Discussion}

In an unpublished technical report of expeditions led by Jonas Nilsson in the Cordillera del Cóndor, 2 records of $P$. scutatus species are mentioned for the region of Paquisha Alto (Ágreda 2004). These reports were based on visual observations.

Freile et al. (2013) stated that P. scutatus is inexplicably rare in Ecuador and there are only a few confirmed observations. The scarcity of records for this species, which is threatened mainly by habitat loss, makes it Endangered in Ecuador (Guerrero 2002). Previously, $P$. scutatus was thought to be restricted to montane forests, mainly cloud forests, between 700 and 1,500 m elevation in northwestern Ecuador and specifically in Imbabura, Carchi, and Santo Domingo de los Tsachilas (Guerrero 2002, McMullan and Navarrete 2017). In northwestern Ecuador, the subspecies is $P$. s. occidentalis (Ridgely and Greenfield 2001a, Snow and Bonan 2017), which is the same subspecies that occurs in the western Andes of Colombia (Fig. 1) (Fjeldså and Krabbe 1990).

These new records were made in the Cordillera del Cóndor, a mountain range isolated from the Andes that is in southeastern Ecuador and northeastern Peru, which is recognized by many authors as a region of great relevance, because of its high level of diversity and endemism in both flora and fauna (Freile et al. 2013, Székely et al. 2016, Ordóñez-Delgado et al. 2017).

Our new records confirm the presence of this species in evergreen montane forest habitat and provide the first evidence of this species in the eastern part of Ecuador. These observations are more than $500 \mathrm{~km}$ from the nearest documented population in the interior of Ecuador. In addition, our records increase the altitudinal range of this species within Ecuador, which was previously known to be between 700 and 1,500 m (Guerrero 2002, McMullan and Navarrete 2017); the new records are between 1,700 and $1,920 \mathrm{~m}$ and correspond to the altitudinal range $(1,100-2,100 \mathrm{~m})$ which has been reported in Peru (Schulenberg et al. 2010).

We are able to confirm that the individuals in the Cordillera del Cóndor belong to P. s. masoni, a subspecies that has not been previously recorded from Ecuador. Until now, this subspecies was thought to be restricted to the central Andes of Peru, between the regions of Amazonas and Pasco (Schulenberg et al. 2010, Snow and Bonan 2017). Our new records are over $200 \mathrm{~km}$ north of the region known as Fundo Alto Nieva $\left(05^{\circ} 39^{\prime} 20^{\prime \prime} \mathrm{S}\right.$, $\left.077^{\circ} 57^{\prime} 05^{\prime \prime} \mathrm{W}\right)$, from where the nearest Peruvian records of this species originate (eBird 2017, Hornbuckle 1999). 


\section{Acknowledgements}

We thank the Departamento de Ciencias Biológicas of the Universidad Técnica Particular de Loja for its institutional support. LOD thanks José María Loaiza for helping to confirm the identification of the subspecies. In addition, we thank the Lundin Gold Inq., who financed the faunal evaluations in the Cordillera del Cóndor. During our fieldwork, we had the valuable collaboration of Dalton Hurtado, a local guide. This work was developed with research permission from the Ministerio del Ambiente No 022-2016-IC-FLO-FAU-DPAZCH-UPN-VS/MA.

\section{Authors' Contributions}

LOD and SE: field data collection, identification and validation of recorded species; LOD, DA and DR wrote the manuscript; IG made the map and geographic analysis. All authors made additions and suggestions to the manuscript.

\section{References}

Ágreda A (2004) Informe Técnico del Proyecto: Una exploración de las aves de la Cordillera del Cóndor que permita generar pautas para su conservación. Corporación Ornitológica del Ecuador, Quito, 53 pp. [Unpublished manuscript].

BirdLife International (2016). Pyroderus scutatus. The IUCN Red List of Threatened Species 2016: e.T22700928A93804956. http://doi. org/10.2305/IUCN.UK.2016-3.RLTS.T22700928A93804956.en. Accessed on: 2017-02-06.

Brinkhuizen D (2014) IBC1066292. Photo of Red-ruffed Fruitcrow Pyroderus scutatus occidentalis at Otún Quimbaya Sanctuary, Colombia. https://www.hbw.com/ibc/1066292. Accessed on: 201707-01.

eBird (2017) eBird: an online database of bird distribution and abundance. eBird, Ithaca, New York. https://www.ebird.org. Accessed on: 2017-06-05.

Fjeldså, J, Krabbe N (1990) Birds of the High Andes. Zoological Museum, University of Copenhagen, $876 \mathrm{pp}$.

Freile J, Ahlman R, Brinkuizen D, Greenfield P, Solano-Ugalde A, Navarrete L, Ridgely R (2013) Rare birds in Ecuador: first annual report of the Committee of Ecuadorian Records in Ornithology (CERO). Avances en Ciencias e Ingenierías 5 (2): B24-B41. http:// doi.org/10.18272/aci.v5i2.135

Guerrero M (2002) Cuervo Higüero Golirrojo-Pyroderus scutatus. In: Granizo T, Pacheco C, Ribadeneira MB, Guerrero M, Suárez L (Eds) Libro rojo de las aves del Ecuador. SIMBIOE/Conservación
Internacional/EcoCiencia/Ministerio del Ambiente/UICN, Quito, 176.

Hornbuckle J (1999) The birds of Abra Patricia and the upper río Mayo, San Martin, north Peru. Cotinga 12: 11-28.

Intervales B (2011) Pyroderus scutatus feeding at Ribeirao Grande/SP. http://www.wikiaves.com.br/490939\&t=s\&s=11389. Accessed on: 2017-02-25.

Jadán, O, Aguirre Z (2011) Flora de los Tepuyes de la Cuenca Alta del Río Nangaritza, Cordillera del Cóndor. In: Guayasamin JM, Bonacorso E (Eds) Evaluación Ecológica Rápida de la Biodiversidad de los Tepuyes de la Cuenca Alta del Río Nangaritza, Cordillera del Cóndor, Conservación Internacional, Ecuador, 41-48. http://doi. org/10.1896/054.058.0104

Kirwan G, Green G, Barnes E (2011). Cotingas and manakins. Christopher Helm, London, 624 pp.

McMullan M, Navarrete L (2017) Fieldbook of the Birds of Ecuador, including the Galapagos Islands and Common Mammals. 2nd edition. Ratty Ediciones, Quito, 228 pp.

Ministerio del Ambiente del Ecuador (2013) Sistema de Clasificación de los Ecosistemas del Ecuador Continental. Subsecretaría de Patrimonio Natural, Quito, 232 pp.

Ordóñez-Delgado L, López F, Reyes-Bueno F (2017). Primer Registro de Tinamú Serrano Nothocercus bonapartei (Tinamiformes: Tinamidae) en la cordillera del Cóndor, sureste de Ecuador. Revista Ecuatoriana de Ornitología 1: 1-6 http://doi.org/10.18272/reo. v0i1.487

Ordóñez-Delgado L (2017). XC387672, XC387670, XC387768, XC387769, XC387770, songs of Red-ruffed Fruitcrow Pyroderus scutatus masoni. http://www.xeno-canto.org/species/Pyroderusscutatus?query=rec\%3Aleonardo. Accessed on: 2017-09-28.

Ridgely R, Greenfield P (2001a) The Birds of Ecuador: status, distribution, and taxonomy. Vol. 1. Cornell University Press, Ithaca, 848 pp.

Ridgely R, Greenfield P (2001b) The Birds of Ecuador. Vol. 2. Field Guide. Cornell University Press, Ithaca, $740 \mathrm{pp}$.

Schulenberg T, Stotz D, Lane D, O’Neill J, Parker T (2010) Birds of Peru. Revised edition. Princeton University Press, Princeton, 656 pp.

Snow D, Bonan A (2017) Red-ruffed Fruitcrow (Pyroderus scutatus). In: del Hoyo J, Elliott A, Sargatal J, Christie DA, de Juana E (Eds) Handbook of the Birds of the World Alive. Lynx Edicions, Barcelona. http://www.hbw.com/node/57049. Accessed on: 2017-02-25.

Stotz D, Fitzpatrick J, Parker T, Moskovits D (1996) Neotropical birds: ecology and conservation. University of Chicago Press, Chicago. $483 \mathrm{pp}$.

Székely P, Cogălniceanu D, Armijos-Ojeda D, Székely D, OrdóñezDelgado L (2016) Amphibia, Anura, Bufonidae, Rhaebo ecuadorensis Mueses-Cisneros, Cisneros-Heredia \& McDiarmid, 2012, and Anura, Hylidae, Phyllomedusa tarsius (Cope, 1868): range extensions and first records for Zamora-Chinchipe province, Ecuador. Check List 12 (5): 1966. https://doi.org/10.15560/12.5.1966 